\title{
USE OF 3D-VISUALIZATION MEDIA IN NUCLEOPHILIC SUBSTITUTION REACTION MATERIAL TO IMPROVE STUDENTS' CONCEPT MASTERY
}

\author{
Dessi Nur Adiska ${ }^{*}$, Liliasari ${ }^{1}$ and lqbal Musthapa ${ }^{1}$ \\ ${ }^{1}$ Department of Chemistry Education, Faculty of Mathematics and Natural Sciences, \\ Universitas Pendidikan Indonesia, Jl. Dr. Setiabudhi, Kota Bandung, 40154, Indonesia \\ "E-mail: dessinuradiska094@gmail.com
}

Received: 20 October 2020; Accepted: 02 December 2020; Published: 31 December 2020

\begin{abstract}
Development of technology is increasingly rapid today, including in the field of education. Technological developments are sometimes not used properly in the learning process, so that students not actively studying in class. The purpose of this study was to determine the effect of using 3D visualization media on nucleophilic substitution reaction material to improve students' concept mastery. Research method used was a quasiexperiment with pre-test and post-test design, involved 68 students from two different universities in West Java. The test instrument to measure concept mastery consisted of nine reasoned multiple-choice questions. The results showed that the use of 3D visualization media in nucleophilic substitution reaction materials can improve students' mastery of concepts. Based on the N-gain calculation results, University A was better than University B except for the indicators of determining that obtained a medium category and sorting that obtained a low category. There were four indicators of concept mastery used, including determining, analyzing, linking, and sorting indicators.
\end{abstract}

Keywords: 3D visualization media, concept mastery, nucleophilic substitution reactions

DOI : https://doi.org/10.15575/jtk.v5i2.9820

\section{INTRODUCTION}

Today, technology continues to develop in all fields, including education. The learning process carried out so far has not used the technology properly, so it is difficult to achieve the desired learning targets and make students active during the teaching and learning process.

One of the technologies that can be used in chemistry learning is ChemDraw application, because it can show molecules in 2D and 3D. So that students do not have to imagine molecules abstractly. In addition, ChemDraw application can be used to help lecturers prepare for learning so that students can be actively involved in it and improve their ability to understand chemistry better.
Chemistry is a challenging topic for some students because it requires mastery of abstract concepts that are important in understanding molecular structures, physical properties, and complex chemical transformations (Bharathy, 2015; Raiyn \& Rayan, 2015). Learning that uses technology such as three-dimensional simulations can reduce the cognitive load and thus support active learning compared to learning with two-dimensional illustrations (Urhahne et al., 2009).

Based on previous research, learning using computer programs potentially improve the students' chemical abilities to visualize molecules in three dimensions. This can make it easier to understand chemical materials (Appling \& Peake, 2004). 
One of the materials that requires the use of technology is organic chemistry, because this material requires students to understand the space and arrangement of organic compounds (Hornbuckle et al., 2014). Organic chemistry also requires students to understand three-dimensional molecules from two-dimensional molecular shapes, imagine objects from different perspectives, and visualize the effects of operations such as rotation, reflection, and inversion (Barnea \& Dori, 1999; Wu \& Shah, 2004).

Organic chemistry materials that was considered difficult by students included bimolecular nucleophilic substitution reactions (48\%) and unimolecular nucleophilic substitution reactions (83\%) (Rinaningsih, 2014). So that students understand the nucleophilic substitution reaction material well, concept mastery must be improved, one of which is by using technology such as 3D visualization media. In addition, students who have studied the polarity of compounds, steric effects, and stereoisomers will find it easier to understand nucleophilic substitution reactions. Because the material is the basis for further mastery of the concept. So that when using 3D visualization media, students can apply the last theory easily, even though the material will be repeated before studying nucleophilic substitution reactions.

Concept mastery is an ability obtained from learning activities, after the learning process is carried out, the success of the process can be seen in the concept mastery test. Concept mastery is also the ability to express a material which is presented in a form that is easier to understand, the ability to provide an interpretation and the ability to apply it (Dimyati \& Mudjiono, 2002).

Concept mastery is an ability that shows the thinking level of students before and after learning activities (Firman, 2018). Students who can master the concept of material well will be able to solve the problems given well, and thus will increase student learning outcomes (Widiyowati, 2014).
Previous research used visualization media to show 3D structures, with spheres and sticks show the shape of the molecular structure made by the researchers, and the written structure show 2D shapes (Abraham et al., 2010). Whereas in this study, students are expected not only to understand the 3Dvisualization of a molecule, but to be able to predict compounds through the $\mathrm{S}_{\mathrm{N}} 1$ or $\mathrm{S}_{\mathrm{N}} 2$ reaction mechanism and based on these data students can determine which $\mathrm{C}$ atom is more reactive in the reaction.

Previous research has shown that the use of 3D-visualization media can help students understand stereochemistry, but this research has not yet discussed whether the media can be used to explain nucleophilic substitution reactions or not (Setyarini et al., 2017). 3Dvisualization media is a media that able to display 3D-visualizations of any desired structure as long as the molecules are available in the media. The 3D-visualization media used in this study was ChemOffice application which consists of three core applications, namely ChemDraw, ChemFinder, and Chem3D. So that in one application can display a lot of data needed compared to other media (Zielesny, 2005).

In addition, research that has been done before aims to know the effectiveness of media to help students be more active in learning, but this research does not see the extent of chemistry concept understanding that students get (Raiyn \& Rayan, 2015). Based on the description above, the researcher considers it necessary to study the mechanism of organic nucleophilic substitution reaction based on 3D-visualization to improve students' concept mastery.

\section{RESEARCH METHOD}

The research method used was a quasiexperimental with pre-test and post-test design. Learning was carried out in three online meetings via Google Classroom. The researcher uploaded a video made using the Bandicam application which contains explanations in the form of power point slides. 
Meanwhile, the pre-test and post-test were done via google form.

At the first meeting, students were given a pretest for 50 minutes. At the second meeting, learning was carried out by providing a video containing power point material, 3D visualization media and tasks that had to be done to see students understanding of each concept for 100 minutes. At the third meeting, students were given a post-test for 50 minutes. The data to be calculated was obtained from the pre-test and post-test results.

The research subjects were even semester students who contracted the Organic Chemistry course 1 in Chemistry Study Program. The research was conducted at two different universities in West Java. Each student from the two universities was previously taught by the same lecturer, so the knowledge gained was the same. University A consisted of 37 students with 6 males and 31 females and university B included 31 students with 7 males and 24 females. Students from both universities were student of 2019 class. All students were willing to take part in the learning that is carried out. Two universities were used to see differences in their initial knowledge, and whether learning using 3D visualization media could affect the students' mastery of the concept or not.

The test given was reasoned multiple choice test as many as 9 questions. Each question received 11 points, 5.5 points respectively for multiple choice and reason. The maximum score for the whole test is 99 and the minimum score is 60 .

The concept mastery indicator used from the Revised Bloom Taxonomy including indicators of determining, analyzing, linking, and sorting. The data obtained were processed using excel, by performing tests of normality, homogeneity, significance, and N-gain.

\section{RESULT AND DISCUSSION}

The normality, homogeneity, significance, and $\mathrm{N}$-gain tests were performed on the concept mastery data obtained from the pre-test and post-test results. Normality, homogeneity, and significance tests were carried out as a prerequisite test to determine whether the data is classified as a parametric or nonparametric test. The calculation results can be seen in Table 1.

Table 1. Assumption Test Results for Pre-test Post-test Concept Mastery of Universities A and B

\begin{tabular}{|c|c|c|c|c|c|c|}
\hline Data & $\mathbf{N}$ & $\begin{array}{c}\text { Average } \\
\text { Score }\end{array}$ & Normality & Homogeneity & $\begin{array}{c}\text { Significance } \\
\text { Test }\end{array}$ & $\begin{array}{l}\text { Asymp. Sig. } \\
\text { (2-tailed) }\end{array}$ \\
\hline Pre-test University A & \multirow[t]{2}{*}{37} & 71.65 & Normal & \multirow{2}{*}{ Homogeneous } & \multirow{2}{*}{$\begin{array}{l}\mathrm{H}_{0} \text { rejected } \\
\text { (significantly } \\
\text { different) }\end{array}$} & \multirow{2}{*}{0.000} \\
\hline Post-test University A & & 82.77 & Not normal & & & \\
\hline Pre-test University B & \multirow[t]{2}{*}{31} & 35.19 & Normal & \multirow[t]{2}{*}{ Heterogeneous } & \multirow{2}{*}{$\begin{array}{l}\mathrm{H}_{0} \text { rejected } \\
\text { (significantly } \\
\text { different) }\end{array}$} & \multirow[t]{2}{*}{0.000} \\
\hline Post-test University B & & 51.39 & Normal & & & \\
\hline
\end{tabular}

The normality test was carried out using the Shapiro-Wilk statistic type, because the amount of data was below $50(\mathrm{~N}<50)$, with a significance level of $\alpha=0.05$. The data in Table 1 shows that post-test in University $A$ is not normally distributed because the post-test significance value is smaller than 0.05 , while the University B pre-test-post-test is normally distributed because the significance value is greater than 0.05 .
Based on Table 1, the homogeneity test result shows that the pre-test-post-test data from University $A$ is homogeneous because the significance value is greater than 0.05 , meaning that the data population comes from the same variance. But the pre-test-post-test result of the University $B$ is not homogeneous, this shows that the data population comes from the different variances. 
The data obtained is not normally distributed and not homogeneous, so that the data is processed using non-parametric statistics, namely the Wilcoxon test. This is because the data does not qualify the parametric statistical test requirements, where the data of the two universities must be normally distributed and homogeneous.

Based on the assumption test results, it can be concluded that there is a significant difference between the pre-test and post-test at the two universities because the significance value is smaller than 0.05. It means that the use of 3D visualization media can improve students' mastery of concepts at both universities $A$ and B.

In addition, the $\mathrm{N}$-gain test on each indicator of concept mastery and concept label was carried out to determine the difference between the pre-test and post-test at the two universities. The $\mathrm{N}$-gain calculation result can be seen in Table 2.

Table 2. N-gain Calculation Result of Universities A and B

\begin{tabular}{|c|c|c|c|c|c|}
\hline University & N & Post-test Average & Pre-test Average & \% N-gain Average & Conclusion \\
\hline A & 37 & 82.77 & 71.65 & 41 & Medium \\
\hline B & 31 & 51.39 & 35.19 & 25 & Low \\
\hline
\end{tabular}

$\mathrm{N}$-gain calculation result in Table 2 shows that the use of 3D visualization media can improve students' mastery of concepts at both universities. University $A$ is better than University B, classified in medium and low category respectively. The medium category for the value between $0.7\langle g\rangle \geq 0.3$ and the low category for the value between $<\mathrm{g}><0.3$.

The average pre-test obtained by University $A$ is higher than University $B$, it means that students from University $A$ have better initial knowledge. This makes it easier to connect the material that has just obtained with the previous material, which is shown by the increase in post-test scores that are higher than University B. But overall, the scores of the two universities have increased. In addition, Ngain is calculated to see the difference between pre-test and post-test on each indicator of concept mastery.
The increase that occurs is the result of achieving the principles for learning concepts. It means that the students are able to use 3D visualization media which can make it easier for them to learn concepts (Slameto, 2003).

Table 3 shows that the two universities have an increase in each indicator of concept mastery. The highest score indicator obtained by University $A$ is in the medium category as well as for University B. Overall University A gets better score than University $B$. This shows that University A students have a better understanding of previous concepts, so it is easy to connect newly obtained concepts. Students with good academic abilities tend to have extensive knowledge of the topics to be studied and will easily understand and remember the material compared to students who have low initial knowledge (Fauzi, 2013).

Tabel 3. Increased N-gain of Concept Mastery Indicators

\begin{tabular}{|c|c|c|c|c|c|}
\hline \multirow{2}{*}{ Indicator } & \multirow{2}{*}{ Question } & \multicolumn{2}{|c|}{ University A } & \multicolumn{2}{c|}{ University B } \\
\cline { 3 - 6 } & & \% N-gain & Conclusion & \% N-gain & Conclusion \\
\hline Determine & 1,2 & 64 & Medium & 51 & Medium \\
\hline Analyze & $3,6,8$ & 43 & Medium & 18 & Low \\
\hline Connect & 4,9 & 32 & Medium & 19 & Low \\
\hline Sort & 5,7 & 10 & Low & 24 & Low \\
\hline
\end{tabular}

The low level of concept mastery of university B students is influenced by time. This is because students who have low initial abilities need more time to be able to connect the initial and new knowledge (Prasinta, 2018).
The increase that occurs in the indicators of determining, connecting, and sorting which is classified into C-3 indicates that there is an increase in the ability to use the principles, rules, and methods learned in new situations 
Use of 3D-Visualization Media in Nucleophilic Substitution Reaction Material to Improve Students' Concept Mastery

or concrete situations (other than what they have learned). Whereas the increase in the analyzing indicator which is classified into C-4 indicates that there is a better increase in the ability to decompose the faced information into its components, so that the structure and relationship

between

information components becomes clear. In addition to the $\mathrm{N}$-gain test of the concept mastery indicator, it was also carried out on each concept label used. Table 4 shows the increased mastery of concept labels.

Table 4. Increased Mastery of Concept Labels

\begin{tabular}{|l|c|c|c|c|c|}
\hline \multirow{2}{*}{ Concept Labels } & \multirow{2}{*}{ Question } & \multicolumn{2}{c|}{ University A } & \multicolumn{2}{c|}{ University B } \\
\cline { 3 - 6 } & & \% N-gain & Conclution & \% N-gain & Conclusion \\
\hline Polarity of compounds & 1 & 99.00 & High & 55.78 & Medium \\
\hline Steric effects & 2 & 70.99 & High & 49.13 & Medium \\
\hline Absolute configuration & 3 & 44.00 & Medium & 30.47 & Medium \\
\hline Stereoisomers & 4 & 24.75 & Low & 32.37 & Medium \\
\hline Carbocation & 7 & 2.20 & Low & 30.48 & Medium \\
\hline $\mathrm{S}_{\mathrm{N}} 1$ reaction mechanisms & 8 & 17.07 & Low & 15.51 & Low \\
\hline $\mathrm{S}_{\mathrm{N}} 2$ reaction mechanisms & 5,6 & 61.99 & Medium & 5.99 & Low \\
\hline $\begin{array}{l}\mathrm{S}_{\mathrm{N}} 1 \text { and S } 2 \text { reaction } \\
\text { mechanisms }\end{array}$ & 9 & 34.88 & Medium & 13.45 & Low \\
\hline
\end{tabular}

Based on Table 4, increased mastery of concepts based on concept labels, University A students obtain a high category on the polarity of compounds and steric effects concepts. This is because the difference between their initial knowledge is much different from their final knowledge, meaning that $3 \mathrm{D}$ visualization media is very helpful for solving this concept. The medium category is obtained on three concept labels, namely absolute configuration, $\mathrm{S}_{\mathrm{N}} 2$ reaction mechanism, $\mathrm{S}_{\mathrm{N}} 1$ and $\mathrm{S}_{\mathrm{N}} 2$ reaction mechanisms. The low category is obtained in the concept of stereoisomers, carbocation, and $S_{N} 1$ reaction mechanisms.

Meanwhile, University B is in the medium category on five concepts, namely polarity of compounds, steric effects, absolute configuration, stereoisomers, and carbocation. This shows that there is a difference between initial and final knowledge, meaning that the $3 \mathrm{D}$ visualization media used helps solve the concept.

At University $B$, the low category is obtained on three concept labels, namely the $S_{N} 1$ reaction mechanisms, $S_{N} 2$ reaction mechanisms, $\mathrm{S}_{N} 1$ and $\mathrm{S}_{N} 2$ reaction mechanisms. This shows that students' initial knowledge is not much different from final knowledge, meaning that $3 \mathrm{D}$ visualization media helps a little in solving this concept.

\section{CONCLUSION}

The results showed that the use of 3Dvisualization media could improve students' concept mastery at both universities. In general, University A obtained medium Ngain category and University B obtained low $\mathrm{N}$-gain category. The $\mathrm{N}$-gain result for each concept mastery indicator of University A obtained the highest results on 3 indicators with medium category. While University B obtained the highest result on the first indicator with medium category. In addition, when viewed on each concept label, University A obtained the highest score with high category on the concept of compound polarity and steric effects. While University B obtained the highest score with medium category on the concept of compound polarity, steric effect, stereoisomer, and carbocation.

The implication for lecturers with the results of this study is that lecturers can use 3Dvisualization media to make it easier to explain a reaction that will take place through the $S_{N} 1$ or $\mathrm{S}_{\mathrm{N}} 2$ reaction mechanism. For students, the 3D-visualization media can help make it easier to master the nucleophilic substitution reaction material. For the next researcher who wants to continue this research, it is necessary to carry out further analysis of the data that can be generated through the media, so that more data is needed.

Jurnal Tadris Kimiya 5, 2 (December 2020): 213-219 


\section{REFERENCES}

Abraham, M., Varghese, V., \& Tang, H. (2010). Using molecular representations to aid students understanding of stereochemical concepts. Journal of Chemical Education, 87(12), 1425-1429. https://doi.org/10.1021/ed100497f

Appling, J. R., \& Peake, L. C. (2004). Instructional technology and molecular visualization. Journal of science education and technology, 13(3), 361$365 . \quad$ Retrieved from https://www.jstor.org/stable/40186655

Barnea, N., \& Dori, Y. J. (1999). High-school chemistry students' performance and gender differences in a computerized molecular modeling learning environment. Journal of Science Education and Technology, 8, 257-271. https://doi.org/10.1023/A:10094365097 53

Bharathy, J. B. (2015). Importance of computer assisted teaching \& learning methods for chemistry. Science, 3(4), 11-16. https://doi.org/10.11648/j.sjedu.s.20150 30401.13

Dimyati \& Mudjiono. (2002). Belajar dan Pembelajaran. Jakarta: Rineka Cipta dan Depdikbud.

Fauzi, A. (2013). Pengaruh kemampuan akademik siswa terhadap keterampilan metakognitif hasil belajar biologi siswa kelas $\mathrm{X}$ dengan penerapan strategi pembelajaran kooperatif di Malang. Jurnal Pendidikan Hayati, 1(1), 56-69. Retrieved from https://www.researchgate.net/publicati on/322291755_Pengaruh_Kemampuan_ Akademik_Terhadap_Keterampilan_Met akognitif_Dan_Retensi_Siswa_Pada_Pem belajaran_Biologi_Kelas_X_Dengan_Pen erapan_Strategi_Jigsaw

Firman, H. (2018). Asesmen Pembelajaran Kimia. Bandung: Sekolah Pascasarjana Universitas Pendidikan Indonesia.
Hornbuckle, S. F., Gobin, L., \& Thurman, S. N. (2014). Spatial reasoning: improvement of imagery and abilities in sophomore organic chemistry. Perspective to enhance student learning. Contemporary Issues in Education Research, 7(1), 45-50. https://doi.org/10.19030/cier.v7i1.8311

Prasinta, J. D., Kadaritna, N., \& Tania, L. (2018). Efektivitas model pembelajaran ADI dalam meningkatkan penguasaan konsep siswa berdasarkan kemampuan akademik. Jurnal Pendidikan dan Pembelajaran Kimia, 7(2), 1-14. Retrieved from http://jurnal.fkip.unila.ac.id/index.php/J PK/article/view/16222

Raiyn, J., \& Rayan, A. (2015). How chemicals' drawing and modelling improve chemistry teaching in colleges of education. World Journal of Chemical Education, 3(1), 1-4. https://doi.org/ 10.12691/wjce-3-1-1

Rinaningsih, R. (2014). Implementasi model perkuliahan terpadu soroganbandongan untuk menentukan pemahaman mahasiswa dalam mempelajari mekanisme reaksi. Jurnal Pengajaran MIPA, 19(2), 266-274. https://doi.org/10.18269/jpmipa.v19i2.4 69

Setyarini, M., Liliasari, L., Kadarohman, A., \& Martoprawiro, M. A. (2017). Efektivitas pembelajaran stereokimia berbasis visualisasi 3D molekul untuk meningkatkan kemampuan spasial. Cakrawala Pendidikan, 36(1), 91101. https://doi.org/10.21831/cp.v36i1.1108 2

Slameto. (2003). Belajar dan Faktor-faktor yang Mempengaruhinya. Jakarta: Rineka Cipta.

Urhahne, D., Nick, S., \& Schanze, S. (2009). The effect of three-dimensional simulations on the understanding of chemical 
structures and their properties. Research in science education, 39(4), 495-513. Retrieved from https://www.learntechlib.org/p/104351/

Widiyowati, I. I. (2014). Hubungan pemahaman konsep struktur atom dan sistem periodik unsur dengan hasil belajar kimia pada pokok bahasan ikatan kimia. Jurnal Pendidikan, 3(4), 99- 116. Retrieved from https://jurnal.unej.ac.id/index.php/panc aran/article/view/989

Wu, H. K., \& Shah, P. (2004). Exploring visuospatial thinking in chemistry learning. Science Education, 88, 465492.

http://dx.doi.org/10.1002/sce.10126

Zielesny, A. (2005). Chemistry software package ChemOffice Ultra 2005. Journal of Chemical Information and Modeling, 45(5), $1474-1477$. https://doi.org/10.1021/ci050273j 